\title{
PENGARUH LAMA PEREBUSAN TERHADAP PENERIMAAN KONSUMEN PADA KUE BERBAHAN DASAR TEPUNG KETAN
}

\author{
Berry Tri Yoka, S.TP ${ }^{(1)}$, dan Hermiza Mardesci ${ }^{(2)}$ \\ (1) Alumni Teknologi Pangan Faperta UNISI \\ (2) Dosen Teknologi Pangan Faperta UNISI \\ mimzaaci@yahoo.co.id
}

\begin{abstract}
Abstrak
Penelitian ini bertujuan untuk mengetahui lama waktu perebusan kue berbahan dasar tepung ketan yang tepat terhadap penerimaan konsumen. Rancangan percobaan penelitian ini adalah menggunakan Rancangan Acak Lengkap (RAL) dengan empat perlakuan lama perebusan $(A=4$ menit lama perebusan, $B=5$ menit lama perebusan, $C=6$ menit lama perebusan, $D=7$ menit lama perebusan). Analisa dilakukan untuk menentukan kadar air, kadar pati, dan organoleptik (warna, aroma, rasa dan tekstur). Untuk hasil terbaik dari uji penerimaan panelis terhadap kue berbahan dasar tepung ketan adalah pada perlakuan A (7 menit lama perebusan) yaitu dengan kadar air 51,8301\%, kadar pati 45,3964\%, uji organoleptik warna 3,7\%, aroma $3,2 \%$, rasa $3,3 \%$, dan tekstur $3,3 \%$. Kue yang berbahan dasar tepung ketan yang direbus terlalu lama kurang disukai oleh konsumen tetapi sebaliknya kue berbahan dasar tepung ketan yang direbus dengan waktu yang singkat lebih di sukai oleh konsumen.
\end{abstract}

Kata kunci : Kue basah, Kue Klepon, Tepung ketan, Perebusan

\section{PENDAHULUAN}

Kue tradisional biasanya dijual di pasar-pasar tradisional hanya pada waktu pagi hari, walaupun ada beberapa tempat yang menjualnya hingga siang bahkan sore hari. Ada juga jenis kue kering yang dijual di toko oleh-oleh dan sejenisnya, karena lebih tahan lama. Masyarakat biasa mengonsumsi kudapan tradisional ini bersama teh atau kopi pada saat bersantai di pagi hari atau sore hari. Kue tradisional Nusantara cukup digemari karena harganya yang relatif murah, dan rasanya yang ringan dan akrab di lidah, sehingga dapat dikonsumsi di setiap waktu, jadi santapan saat kumpul bersama teman atau keluarga dan semacamnya, serta fisiknya yang mudah dibawa. Namun, beberapa jenis kue tradisional Nusantara tidak dapat bertahan lama atau cepat basi, oleh karena itu biasanya langsung harus dihabiskan di hari yang sama. Hal ini disebabkan makanan ini menggunakan bahan-bahan alami seperti santan dan tanpa pengawet buatan. Sebagian besar kue-kue tradisional Nusantara menggunakan bahan dasar tepung ketan.

Secara umum ada beberapa kue yang menggunakan tepung ketan sebagai bahan dasar dalam pengolahannya. Contoh kue yang menggunakan tepung ketan sebagai bahan dasar dalam pengolahannya adalah dodol, klepon, kue bugis dan lain-lainnya.

Salah satu teknik memasak yang digunakan dalam pengolahan kue berbahan dasar tepung ketan adalah dengan cara direbus. Contoh kue yang berbahan dasar tepung ketan yang 
menggunakan teknik perebusan dalam pemasakan adalah kue klepon.

Untuk kue yang direbus, hal yang perlu diperhatikan adalah jumlah air perebusannya. Air perebus harus dapat merendam seluruh permukaan kue, agar masaknya rata. Secara umum suhu air yang digunakan untuk merebus adalah $100^{\circ} \mathrm{C}$ dengan ciri-ciri air mendidih, cairan akan menggelembung dan memecah di atas permukaan air.

Menurut Alamsyah, dkk (2006) kue yang berbahan dasar tepung ketan yaitu kue klepon, teknik memasaknya dengan cara direbus dalam air mendidih selama lebih kurang lima menit. Jika sudah mengapung diangkat dan ditiriskan. Kue yang terbuat dari tepung ketan tidak boleh dimasak terlalu lama untuk menghindari agar kue tidak sampai pecah dan bentuknya tidak berubah karena sifat ketan cepat masak seperti pada pembuatan klepon (Anonim, 2012). Kue yang berbahan dasar tepung ketan yang yang dimasak terlalu cepat akan menghasilkan kue yang berbahan dasar tepung ketan yang masih mentah (tidak kenyal). Salah satu cara agar kue yang berbahan dasar tepung ketan lebih disukai oleh konsumen adalah menetapkan lamanya waktu perebusan yang tepat pada proses pengolahan kue yang berbahan dasar tepung ketan.

Dengan perlakuan menetapkan lamanya waktu perebusan yang tepat pada proses pengolahan kue yang berbahan dasar tepung ketan, dengan ini penulis telah melakukan penelitian tentang "Pengaruh Lama Perebusan terhadap Penerimaan Konsumen pada Kue Berbahan Dasar Tepung Ketan”.

Selama ini pemasakan kue yang berbahan dasar tepung ketan seperti kue klepon hanya direbus dalam air mendidih lebih kurang lima menit atau setelah mengapung baru diangkat. Untuk kue yang terbuat dari tepung ketan hal utama yang perlu diperhatikan adalah proses pemasakan tidak boleh terlalu lama. Hal ini bertujuan untuk menghindari agar kue tidak sampai pecah dan bentuknya tidak berubah karena sifat ketan cepat masak seperti pada pembuatan kue klepon. Sedangkan kue yang berbahan dasar tepung ketan yang yang dimasak terlalu cepat akan menghasilkan kue yang berbahan dasar tepung ketan yang masih mentah (tidak kenyal).

Permasalahan yang menjadi dasar dilakukan penelitian ini adalah berapa lama waktu yang tepat untuk merebus kue yang berbahan dasar tepung ketan.

\section{Tujuan Penelitian}

Tujuan penelitian ini adalah :

1. Untuk mengetahui pengaruh lama perebusan dalam pengolahan kue yang berbahan dasar tepung ketan.

2. Untuk mengetahui hasil terbaik dari uji penerimaan panelis terhadap kue yang berbahan dasar tepung ketan.

\section{Manfaat Penelitian}

Manfaat penelitian ini adalah untuk memberikan informasi kepada masyarakat tentang lama perebusan yang tepat pada pengolahan kue yang berbahan dasar tepung ketan.

\section{HASIL DAN PEMBAHASAN}

\section{Kadar Air}

Kadar air merupakan banyaknya air yang terkandung dalam bahan yang dinyatakan dalam persen. Rata-rata pengaruh lama perebusan kue yang berbahan dasar tepung ketan terhadap kadar air dapat dilihat pada Tabel 1. 
Tabel 1. Hasil Pengaruh Perebusan terhadap Kadar Air Kue Berbahan Dasar Tepung Ketan

\begin{tabular}{|l|l|}
\hline \multicolumn{1}{|c|}{ Perlakuan } & \multicolumn{1}{c|}{ Rata-rata (\%) } \\
\hline $\mathrm{A}=4$ menit lama perebusan & 51,83 \\
\hline $\mathrm{B}=5$ menit lama perebusan & 51,69 \\
\hline $\mathrm{C}=6$ menit lama perebusan & 52,33 \\
\hline $\mathrm{D}=7$ menit lama perebusan & 53,04 \\
\hline
\end{tabular}

Hasil sidik ragam dari perlakuan perebusan dalam pembuatan kue yang berbahan dasar tepung ketan tidak berbeda nyata pada taraf $5 \%$ terhadap parameter kadar air. Jumlah kadar air tertinggi terdapat pada perlakuan D (7 menit lama perebusan) yaitu sebesar $53,04 \%$ dan jumlah kadar air terendah pada perlakuan B (5 menit lama perebusan) yaitu sebesar $51,69 \%$. Jumlah kadar air yang ada pada kue yang berbahan dasar tepung ketan yang dihasilkan memiliki jumlah kadar air yang tinggi. Hal tersebut disebabkan pada saat proses perebusan dengan suhu $99-100^{\circ} \mathrm{C}$ pada kue yang berbahan dasar tepung ketan terjadi pembentukkan gugus hidroksil dari molekul pati yang menyebabkan banyaknya jumlah air yang diserap oleh kue yang berbahan dasar tepung ketan. Semakin lama proses perebusan semakin banyak jumlah gugus hidrosil yang terbentuk sehingga semakin banyak pula jumlah air yang diserap oleh kue yang berbahan dasar tepung ketan. Hal ini sesuai dengan pendapat Testerand dan Karkalas (1996) Semakin banyak jumlah gugus hidroksil dari molekul pati semakin tinggi kemampuannya menyerap air. Tingginya kadar air juga disebabkan oleh, terjadi penguapan pada sampel kue yang berbahan dasar tepung ketan pada saat pengiriman sampel untuk dianalisa.

Kadar air merupakan salah satu karakteristik yang sangat penting pada bahan pangan, karena kandungan air dalam bahan pangan dapat mempengaruhi kenampakan, tekstur, serta cita rasa pada bahan pangan tersebut. Kadar air dalam bahan pangan ikut menentukan kesegaran dan daya awet bahan pangan tersebut, kadar air yang tinggi mengakibatkan mudahnya bakteri, kapang, dan khamir untuk berkembang biak, sehingga akan terjadi perubahan pada bahan pangan. Kadar air dalam bahan pangan ikut menentukan kesegaran dan daya awet bahan pangan tersebut, kadar air yang tinggi mengakibatkan mudahnya bakteri, kapang, dan khamir untuk berkembang biak, sehingga akan terjadi perubahan pada bahan pangan (Winarno, 1997).

\section{Kadar Pati}

Pati penting dalam makanan terutama yang bersumber dari tumbuhtumbuhan dan memperlihatkan sifatsifatnya, pati terdapat dalam biji-bijian dan umbi-umbian sebagai karakteristik granula pati, pati tidak manis, pati tidak dapat larut dengan mudah dalam air dingin, pati berbentuk pasta dan gel di dalam air panas, pati menyediakan cadangan sumber energi dalam tumbuhtumbuhan dan persediaan energi dalam bentuk nutrisi.

Rata-rata pengaruh perebusan kue yang berbahan dasar tepung ketan terhadap kadar pati dapat dilihat pada Tabel 2. 
Tabel 2. Hasil Pengaruh Perebusan Terhadap Kadar Pati Kue Berbahan Dasar Tepung Ketan

\begin{tabular}{|l|l|}
\hline \multicolumn{1}{|c|}{ Perlakuan } & Rata-rata (\%) \\
\hline $\mathrm{A}=4$ menit lama perebusan & 45,39 \\
\hline $\mathrm{B}=5$ menit lama perebusan & 43,81 \\
\hline $\mathrm{C}=6$ menit lama perebusan & 42,40 \\
\hline $\mathrm{D}=7$ menit lama perebusan & 41,54 \\
\hline
\end{tabular}

Hasil sidik ragam dari perlakuan perebusan dalam pembuatan kue yang berbahan dasar tepung ketan tidak berbeda nyata pada taraf 5\% terhadap parameter kadar pati. Jumlah kadar pati tertinggi terdapat pada perlakuan A (4 menit lama perebusan) yaitu sebesar $45,39 \%$ dan jumlah kadar pati terendah pada perlakuan D (7 menit lama perebusan) yaitu sebesar 41,54\%. Pada saat proses perebusan kue yang berbahan dasar tepung ketan dengan suhu 99$100^{\circ} \mathrm{C}$, amilosa yang terkandung dalam pati tepung ketan terlarut dalam air rebusan. Hal tersebut menyebabkan jumlah kadar pati yang ada di dalam kue yang berbahan dasar tepung ketan berkurang. Semakin lama proses perebusan kue yang berbahan dasar tepung ketan semakin banyak jumlah pati yang hilang dalam kue yang berbahan dasar tepung ketan. Hal ini sesuai dengan pendapat Be Miller dan
Whistler (1996) granula pati mempunyai dua polimer yakni amilosa dan amilopektin yang dapat dipisahkan dengan air panas. Amilosa disebut sebagai fraksi terlarut sedangkan amilopektin disebut sebagai fraksi tidak larut.

\section{Uji Organoleptik}

Uji organoleptik atau uji indera atau uji sensori merupakan cara pengujian dengan menggunakan indera manusia sebagai alat utama untuk pengukuran daya penerimaan terhadap produk. Uji organoleptik dengan memakai skala hedonic dilakukan terhadap warna, aroma rasa dan tekstur pada kue yang berbahan dasar tepung ketan disetiap perlakuan. Hasil uji organoleptik pada kue yang berbahan dasar tepung ketan dapat dilihat pada Tabel 3.

Tabel 3. Skor Rata-rata, Warna, Aroma, Rasa dan Tekstur Kue Berbahan Dasar Tepung Ketan dari Berbagai Perlakuan

\begin{tabular}{|c|c|c|c|c|}
\hline & $\begin{array}{c}\text { Warna } \\
(\mathbf{\%})\end{array}$ & $\begin{array}{c}\text { Aroma } \\
(\mathbf{\%})\end{array}$ & $\begin{array}{c}\text { Rasa } \\
(\mathbf{\%})\end{array}$ & $\begin{array}{c}\text { Tekstur } \\
(\mathbf{\%})\end{array}$ \\
\hline $\mathrm{A}=4$ menit lama perebusan & 3,7 & 3,2 & 3,3 & 3,3 \\
\hline $\mathrm{B}=5$ menit lama perebusan & 3,5 & 3,2 & 3,2 & 3,2 \\
\hline $\mathrm{C}=6$ menit lama perebusan & 3,4 & 3,1 & 3,15 & 3,15 \\
\hline $\mathrm{D}=7$ menit lama perebusan & 3,1 & 3,0 & 3,05 & 3 \\
\hline
\end{tabular}

\section{Warna}

Warna merupakan komponen yang sangat penting untuk menentukan kualitas atau derajat penerimaan suatu bahan pangan. Pada Tabel 3 nilai organoleptik terhadap warna kue yang berbahan dasar tepung ketan berkisar antara $3,1 \%-3,7 \%$ dengan kriteria biasa sampai suka. Nilai tertinggi terhadap warna kue yang berbahan dasar tepung ketan yaitu pada perlakuan A (4 menit lama perebusan) dengan nilai 
3,7\%. Pada perlakuan D (7 menit lama perebusan) merupakan nilai paling rendah dari semua perlakuan dengan nilai organoleptik $3,1 \%$.

Pada pengujian ini tidak terlihat perbedaan yang nyata untuk seluruh perlakuan pada kue yang berbahan dasar tepung ketan. kue yang berbahan dasar tepung ketan yang direbus selama 5 menit dengan suhu $99-100{ }^{\circ} \mathrm{C}$ menghasilkan kue yang berbahan dasar tepung ketan bewarna hijau yang agak pudar sedangkan kue yang berbahan dasar tepung ketan yang direbus dengan waktu 4 menit dengan suhu $99-100{ }^{\circ} \mathrm{C}$ warna yang dihasilkan bewarna hijau agak tua. Semakin lama waktu yang digunakan untuk merebus kue yang berbahan dasar tepung ketan maka kue yang berbahan dasar tepung ketan yang dihasilkan memiliki warna hijau yang semakin memudar. Hal ini sesuai dengan pendapat Mulyaningsih (2007) makanan akan terlihat kurang menarik apabila proses perebusan terlalu lama karena terjadi perubahan warna. Contohnya pada sayuran hijau menjadi memudar. Secara umum pewarna alami tidak stabil pada saat proses pemasakan sehingga warna yang dihasilkan kurang baik.

Penentuan mutu suatu bahan pangan pada umumnya tergantung pada warna, karena warna tampil terlebih dahulu (Winarno, 2004). Secara visual, faktor warna sangat menentukan mutu. Warna juga dapat menarik perhatian para konsumen sehingga dapat menilai atau memberi kesan suka atau tidak suka.

Secara visual, faktor warna sangat menentukan tingkat kesukaan konsumen terhadap produk. Warna juga dapat menarik perhatian para konsumen sehingga dapat menilai atau memberi kesan suka atau tidak suka.

\section{Aroma}

Aroma adalah bau yang ditimbulkan oleh rangsangan kimia yang tercium oleh syaraf-syaraf olfaktori yang berada dalam rongga hidung ketika makanan masuk ke dalam mulut. Pada Tabel 6 nilai organoleptik terhadap aroma kue yang berbahan dasar tepung ketan berkisar antara 3,0 \% - 3,2 \% dengan kriteria biasa. Nilai tertinggi terhadap warna kue yang berbahan dasar tepung ketan yaitu pada perlakuan A (4 menit lama perebusan) dan B (5 menit lama perebusan) dengan nilai 3,2\%. Pada perlakuan D (7 menit lama perebusan) merupakan nilai paling rendah dari semua perlakuan dengan nilai organoleptik 3,0\%.

Pada pengujian ini tidak terlihat perbedaan yang nyata untuk seluruh perlakuan pada kue yang berbahan dasar tepung ketan. kue yang berbahan dasar tepung ketan yang direbus selama 4 menit dengan suhu $99-100{ }^{\circ} \mathrm{C}$ menghasilkan kue yang berbahan dasar tepung ketan beraroma daun pandan yang sudah agak berkurang dari sebelum dilakukannya perebusan. Sedangkan kue yang berbahan dasar tepung ketan yang direbus selama 5 menit dengan suhu 99 $100{ }^{\circ} \mathrm{C}$, aroma daun pandan yang ada di dalam kue yang berbahan dasar tepung ketan berkurang. Berkurangnya aroma daun pandan yang ada di dalam kue yang berbahan dasar tepung ketan seiring dengan lamanya waktu yang digunakan untuk merebus kue yang berbahan dasar tepung ketan. Hal ini sesuai dengan pendapat Wibowo (2012) penggunaan pewarna ekstrak daun pandan sebaiknya jangan dimasak terlalu lama karena aroma cepat hilang.

Aroma menentukan kelezatan bahan makanan cita rasa dari bahan pangan sesungguhnya terdiri dari tiga komponen, yaitu bau, rasa dan rangsangan mulut. Bau yang dihasilkan 
dari makanan banyak menentukan kelezatan bahan pangan tersebut. Dalam hal bau lebih banyak dihubungkan dengan alat panca indera penciuman (Rampengan dkk.,1985).

Bahan makanan umumnya dapat dikenali dengan mencium aromanya. Aroma mempunyai peranan yang sangat penting dalam penentuan derajat penilaian dan kualitas suatu bahan pangan, seseorang yang menghadapi makanan baru, maka selain bentuk dan warna, bau atau aroma akanmenjadi perhatian utamanya sesudah bau diterima maka penentuan selanjutnya adalah cita rasa disamping teksturnya (Rubianty dan Kaseger, 1985).

\section{Rasa}

Rasa merupakan salah satu faktor dalam pengujian organoleptik. Rasa lebih banyak melibatkan indera lidah. Rasa yang enak dapat menarik perhatian konsumen sehingga konsumen lebih cenderung menyukai makanan dari rasanya. Cita rasa dari bahan pangan sesungguhnya terdiri dari tiga komponen yaitu : bau, rasa, dan ransangan mulut.

Pada Tabel 3 nilai organoleptik terhadap rasa kue yang berbahan dasar tepung ketan berkisar antara 3,05 \% - 3,3 $\%$ dengan biasa. Nilai tertinggi terhadap kue yang berbahan dasar tepung ketan yaitu pada perlakuan A (4 menit lama perebusan) dengan nilai 3,3\%. Pada perlakuan D (7 menit lama perebusan) merupakan nilai paling rendah dari semua perlakuan dengan nilai organoleptik 3,05\%.

Berdasarkan penelitian organoleptik yang telah dilakukan menunjukkan bahwa disetiap perlakuan tidak terlihat perbedaan yang nyata. Dalam melakukan pengujian organoleptik, sampel kue yang berbahan dasar tepung ketan yang digunakan merupakan sampel kue yang berbahan dasar tepung ketan yang tidak menggunakan bahan tambah lainnya, seperti gula merah pada kue klepon. Sehingga rasa yang dihasilkan biasa saja. Menurut Soekarto (1985), bahwa rasa merupakan faktor yang penting dalam memutuskan bagi konsumen untuk menerima atau menolak suatu makanan. Meskipun parameter lain nilainya baik, jika rasa tidak enak atau tidak disukai, maka produk akan ditolak.

\section{Tekstur}

Tekstur merupakan sensasi tekanan yang dapat diamati dengan mulut (pada waktu digigit, dikunyah, dan ditelan) ataupun perabaan dengan jari. Keadaan tekstur merupakan sifat fisik dari bahan pangan yang penting. Hal ini mempunyai hubungan dengan rasa pada waktu mengunyah bahan tersebut. Salah satu cara penentuan tekstur suatu bahan pangan adalah memberikan beban terhadap bahan tersebut misalnya dengan pemeriksaan bekas atau tekanan jari (Rampengan dkk, 1985). Pada Tabel 6 nilai organoleptik terhadap tekstur kue yang berbahan dasar tepung ketan berkisar antara $3 \%$ - 3,3 \% dengan kriteria biasa. Nilai tertinggi terhadap rasa kue yang berbahan dasar tepung ketan yaitu pada perlakuan A (4 menit lama perebusan) dengan nilai $3,3 \%$. Pada perlakuan D (7 menit lama perebusan) merupakan nilai paling rendah dari semua perlakuan dengan nilai organoleptik $3 \%$.

Pada pengujian ini tidak terlihat perbedaan yang nyata pada kue yang berbahan dasar tepung ketan. kue yang berbahan dasar tepung ketan yang direbus selama 5 menit dengan suhu 99$100^{\circ} \mathrm{C}$ memiliki tekstur yang lengket dan kenyal. Sedangkan kue yang berbahan dasar tepung ketan yang direbus selama 4 menit dengan suhu $99-100^{\circ} \mathrm{C}$ memiliki tekstur agak lengket dan agak kenyal. 
Hal tersebut menunjukkan bahwa dimana semakin lama waktu yang digunakan untuk merebus kue yang berbahan dasar tepung ketan maka tekstur yang dihasilkan kue yang berbahan dasar tepung ketan akan sangat kenyal ataupun pecah sedangkan kue yang berbahan dasar tepung ketan yang direbus dengan waktu yang lebih singkat maka tekstur kue yang berbahan dasar tepung ketan yang dihasilkan agak kenyal ataupun masih keras. Hal ini sesuai dengan pendapat Anonim (2012) kue yang terbuat dari tepung ketan tidak boleh dimasak terlalu lama untuk menghindari agar kue tidak sampai pecah dan bentuknya tidak berubah karena sifat ketan cepat masak.

\section{KESIMPULAN}

\section{Kesimpulan}

Dari penelitian yang telah dilakukan, dapat disimpulkan :

1. Pengaruh lama perebusan pada pembuatan kue yang berbahan dasar tepung ketan tidak memberikan pengaruh nyata terhadap kadar air, kadar pati, dan uji organoleptik terhadap warna, aroma, rasa dan tekstur.

2. Hasil terbaik dari uji penerimaan panelis terhadap kue yang berbahan dasar tepung ketan yang dihasilkan adalah perlakuan A (4 menit lama perebusan) dengan kadar air 51,83\%, kadar pati $45,39 \%$, uji organoleptik warna $3,7 \%$, aroma $3,2 \%$, rasa $3,3 \%$, dan tekstur $3,3 \%$.

\section{Saran}

Pada pembuatan kue yang perlakuan lama perebusan memiliki tekstur yang sangat lengket. Oleh karena itu, sebaiknya pada penelitian selanjutnya dalam pembuatan kue yang berbahan dasar tepung ketan ditambahkan dengan tepung lain agar kue yang dihasilkan tidak terlalu lengket.

\section{DAFTAR PUSTAKA}

Alamsyah, Yuyun dan R. Sujanto.2006. Kue Basah \& Jajan Pasar.Jakarta: PT Gramedia Pustaka Utama.

Anshori, H. 2012. Cara Membuat Kue Klepon. http://resep69.blogspot. com. Diakses 31 Oktober 2013.

Anonim. 2006. Kadar Amilosa Serealia. http://gunasoraya.blogspot.com. Diakses 23 April 2013. .2012. Resep Kue Basah Klepon. http://daftarpustakablogger.blogs pot.com. Diakses 23 April 2013. .2009. Tepung Ketan. http::// mengerjakantugas.blogspot.com. Diakses 23 April 2013.

Astawan, M. 2006. Membuat Mie dan Bihun. Jakarta:Penebar Swadaya.

BeMiller, J. N. and R. L. Whistler. 1996. Carbohydrates. Di dalam: Fennema, O. R (Ed.). Food Chemistry 3rd Ed. Marcel Dekker Inc., New York. Pp 157224.

Herliza. 2013. Pengaruh Persentasi Gula Kelapa dan Perbandingan Tepung Ketan dengan Pisang Muli terhadap Mutu Dodol Pisang.Tembilahan : Universitas Islam Indragiri.

Juliano. 1972. Kadar Amilosa Serealia. http://gunasoraya.blogspot.com. Diakses 23 April 2013.

Maharani, A.A.P dan A.R.Enisa.2011. Pemanfaatan Air Kapur Sirih. http://www aryaayunda.blogspot. com. Diakses 23 April 2013.

Mudjajanti, E.S. dan L.N. Yulianti, 2004. Membuat Aneka Roti. Jakarta : Penebar Swadaya.

Mulyatiningsih, E. 2007.Teknik-Teknik Dasar Memasak.Yogyakarta : Universitas Negeri Yogyakarta. 
Rampengan, V.J. Pontoh dan D.T. Sembel., 1985.Dasar-Dasar Pengawasan Mutu Pangan.Badan

Kerjasama Perguruan Tinggi Negeri Indonesia Bagian Timur, Ujung Pandang.

Rubianty dan Berty Kaseger, 1985. Kimia Pangan. Badan Kerja Sama Perguruan Tinggi Negeri Indonesia Bagian Timur, Ujung Pandang.

Santoso, H.B. 1993. Pembuatan Gula Kelapa. Yogyakarta : Kanisius. SNI 3751.2009. Tepung Terigu sebagai Bahan Makanan.

Soekarto, Soewarno. 1985. Penilaian Organoleptik. Jakarta : Bharata Kata Aksara.

Soejoetu, 1998. Laporan Penetapan Kadar Air Metode Oven. http://pamilaadhiannisa.wordpres s.com. Diakses 23 April 2013.
Sudarmadji,S., dkk.2003. Analisa Bahan Makanan dan Pertanian. Yogyakarta : Kanisius.

Sugiyono. 2002. Ilmu Pengetahuan Pangan.Bogor : PAU Pangan dan Gizi IPB.

Tester R.F. and J. Karkalas. 1996. Swelling and gelatinization of oatstarches. Cereal Chemistry. 73:271:273

Wibowo, N.T. 2012. Macam dan Fungsi Bahan-Bahan Pada Adonan.http://jendelakokojava.bl ogspot.com. Diakses 23 April 2013.

Winarno, F.G. 2004. Kimia Pangan dan Gizi. Gramedia Pustaka Utama, Jakarta.

1997. Kimia Pangan dan Gizi. Gramedia Pustaka Utama. Jakarta. 